\title{
KETERAMPILAN KEPEMIMPINAN KEPALA MADRASAH DALAM PENGELOLAAN GURU, DAN KARYAWAN
}

\author{
Herman \\ Sekolah Tinggi Agama Islam Teungku Dirundeng Meulahoh \\ herman@staindirundeng.ac.id
}

\begin{abstract}
Abstrak
Artikel ini bertujuan mendeskripsikan keterampilan kepemimpinan kepala madrasah dalam pengelolaan guru dan karyawan. Kepala madrasah sebagai pengelola guru dan karyawan harus memiliki keterampilan dalam mengatur, mengkoordinir dan menggerakan bawahan supaya berperan aktif, kreatif, inovatif dan produktif dalam upaya peningkatan kualitas pendidikan. Penelitian ini menggunakan metode kualitatif dengan pendekatan deskriptif melalui jenis penelitian library research. Teknik analisis data melalui tahapan pengumpulan data, pengolahan data dan menganalisis data yang saling berkaitan dan melengkapi tentang keterampilan kepemimpinan kepala madrasah dalam pengelolaan guru dan karyawan. Berdasarkan hasil pembahasan menunjukkan bahwa kepala madrasah yang sukses dalam mengelola guru dan karyawan harus memiliki beberapa keterampilan kepemimpinan meliputi: 1) keterampilan mengorganisir dan menggerakkan guru, dan keryawan, 2) keterampilan memupuk kepercayaan diri guru, dan karyawan, 3) keterampilan mengembangkan profesi guru, dan karyawan, 4) keterampilan membangun team work yang kompak dan kokoh, dan 5) keterampilan mendorong partisipasi guru, dan karyawan dalam pencapaian tujuan pendidikan di madrasah.
\end{abstract}

Kata Kunci: Keterampilan, Kepemimpinan, Kepala Madrasah, Guru dan Karyawan

\begin{abstract}
This article is aimed to describe school principals' leadership skill in managing teachers and employees. To manage teachers and employees, school principals are in need of leadership skill to manage, coordinate, and encourage them to have active role, become creative, innovative, and productive in improving education quality. The study is performed as a library research adopting qualitative approach and descriptive method. Data analysis is run through interrelated processes of data collection, data processing, and data analysis. Result of study indicated that to become a successful school principal in managing teachers and employees, it requires: 1) skill to organize and encourage teachers and employees, 2) skill to nourish teachers and employees' self-confidence, 3) skill to improve teachers and employees professionalism, 4) skill to build a solid and strong team work, and 5) skill to drive teachers and employees to achieve school goals.
\end{abstract}

Keywords: skill, leadership, school principal, teachers and employees

\section{PENDAHULUAN}

Dalam sebuah organisasi Sumber Daya

Manusia (SDM) merupakan hal yang urgen, krusial, rentan, dan fundamental dalam segenap kegiatann manajemen. ${ }^{1}$ Sumber daya manusia

1 Kasidah, dkk, Kepemimpinan Kepala sekolah dalam Meningkatkan Kinerja Guru Pada sekolah Dasar 
memegang peranan penting, strategis, dan sentral dalam penyelenggaraan program pendidikan. $^{2}$ Penyelengaan pendidikan mustahil berjalan normal, lancar dan tertib tanpa didukung oleh sumber daya manusia yang memadai. "Sumber daya manusia menjadi suatu kekuatan moral dan ruh (jiwa) dalam menggerakkan sebuah organisasi". ${ }^{3}$

Dalampengelolaan dan pengkoodinasian SDM di madrasah membutuhkan seorang pemimpin sebagai motor penggerak bagi guru dan karyawan. ${ }^{4}$ Kepala madrasah dalam kepemimpinan harus bersikap handal dan visioner dalam menggerakkan dan mengkoordinir guru dan karyawan untuk pencapaian tujuan pendidikan. "Kepemimpinan yang handal adalah kepemimpinan yang memiliki sifat, dan bakat kepemimpinan, perilaku pribadi yang baik, dan memiliki pengaruh terhadap orang lain serta mampu menjaling hubungan baik dengan bawahan, dan atasannya" (C.A. Hunt, J.G. \& Hosking, 1988: 92).

Kepala madrasah sebagai pemimpin memiliki kewajiban dan tanggung jawab untuk mengelola guru dan karyawan supaya komit dan konsisten dalam melaksanakan tugas yang diamanahkan kepadanya. Kepala madrasah berkewajiban mengarahkan guru dan karyawan

Luar Biasa, Jurnal Magister Administrasi Pendidikan Pascasarjana Universitas Syiah Kuala, Volume 5, No. 2, Mei 2017, hlm. 127

2 Ahmad Mujaddid, dkk, Pengembangan Sumber Daya Manusia Dalam Pendidikan, Junal Project Pengembangan SDM Dalam Pendidikan, Universitas Islam Negeri Alauddin, Januari 2019, hlm. 2

3 Ahmad Mujaddid, dkk, Pengembangan Sumber Daya Manusia .............., hlm. 3

4 Syafrida, Kepemimpinan Kepala Sekolah, Jurnal Manajer Pendidikan, Volume 9, Nomor, November 2015, hlm. 679 untuk melaksanakan tugas dengan sebaikbaiknya. "Kepmimpinan kepala madrasah harus mampu menggerakkan seluruh potensi tenaga pendidik dan tenaga kependidikan yang ada di madrasah sebagai bentuk pendayagunaan sumber daya manusia dalam pencapaian tujuan pendidikan secara efektif dan efesien". ${ }^{5}$

Kepemimpinan kepala madrasah harus memiliki beberapa keterampilan dalam pengelolaan dan pengembangan sumber daya manusia. Pertama, ia harus memiliki kemampuan mengorganisir, dan membantu staf dalam merumuskan perbaikan program pembelajaran. Kedua, kemampuan memupuk kepercayaan diri guru-guru, dan anggota staf sekolah, Ketiga, kemampuan membangun kerjasama dalam pengembangan program supervisi. Keempat, kemampuan mendorong para personalia sekolah agar turut berpartisipasi dalam usaha-usaha mencapai tujuan sekolah yang dirumuskan (Stephen R. Covey, 1977: 28).

Merujuk peraturan pemerintah, Nomor 28 Tahun 1990, pasal 12 bahwa "Kepala sekolah bertanggung jawab atas penyelenggaraan pendidikan, administrasi sekolah, pembinaan tenaga kependidikan lainnya, dan pendayagunaan serta pemeliharaan sarana dan prasarana'. 'Kemudian diperkuat oleh Permendiknas, Nomor 13 Tahun 2007, ada 5 (lima) kompetensi kepala sekolah mencakup kompetensi kepribadian, manajerial, kewirausahaan, supervisi, dan sosial.

5 Usman, H, Manajemen Teori, Praktik, dan Riset Pendidikan, Jakarta: Bumi Aksara, 2009, hlm. 382 6 Peraturan Pemerintah, Nomor: 28 Tahun 1990, Tentang Pendidikan Dasar, tanggal 10 Juli 1990

7 Peraturan Menteri Pendidikan Nasional, Nomor 13 Tahun 2007, Tentang Standar Kepala Sekolah/ Madrasah 
Selanjutnya Permendiknas tersebut direvisi sehingga lahir Permendiknas, Nomor 6 Tahun 2018 , pasal 15 , ayat 1 yang bunyinya bahwa beban kerja kepala sekolah sepenuhnya untuk melaksanakan tugas pokok manajerial, pengembangan kewirausahaan, dan supervisi kepada guru, dan tenaga kependidikan. ${ }^{8}$

Selamainiterlihatbahwakepalamadrasah sangat lemah keterampilan mempengaruhi, mengarahkan dan menggerakkan guru dan karyawan untuk melaksanakan tugas dengan baik, kurang menjaling kerja sama, kurang memotivasi kerja dan lemah menciptaan rasa kekeluargaan serta kurang mampu membentuk team work yang kompak dan kokoh dalam pencapaian tujuan pendidikan. Kondisi yang demikian dapat beimbas kepada sikap perilaku guru dan karyawan bekerja dengan disiplin, tanggung jawab, berdedikasi dan loyalitas terhadap pimpinannya.

Berdasarkan permasalan tersebut, penulis ingin mendeskripsikan bagaimana keterampilan kepemimpinan kepala sekolah dalam pengelolaan guru dan karyawan. Penelitian ini berfokus terhadap keterampilan kepala madrasah mengorganisir dan mengarahkan guru dan karyawan, keterampilan memupuk kepercayaan diri guru, dan karyawan, keterampilan mengembangkan profesi guru, dan karyawan, keterampilan membangun team work yang kompak dan kokoh, dan keterampilan mendorong partisipasi guru, dan karyawan dalam pencapaian tujuan pendidikan di madrasah.

$$
\text { Melalui kajian keterampilan }
$$

8 Peraturan Menteri Pendidikan Nasional, Nomor 6 Tahun 2018, tentang Penugasan Guru Sebagai Kepala Sekolah kepemimpinan kepala sekolah dalam pengelolaan sumber daya manusia dapat membawa manfaaat bagi kepala sekolah, pengawas dan stake holder pendidikan dalam rangka mengembangkan konsep keterampilan kepemimpinan yang ideal dalam mengelola sumber daya manusia di madrasah. Kemudian bagi pakar pendidikan, dan pemerhati pendidikan dapat menambah wawasan, dan pengalaman baru dalam megembangan teori keterampilan kepemimpinan dalam pengelolaan sumber daya manusia dalam dunia pendidikan.

\section{METODE PENELITIAN}

Penelitian ini menggunakan metode kualitatif dengan pendekatan deskriptif melalui jenis penelitian library research, dengan cara membaca beberapa literatur baik berupa buku, jurnal, majalah, bulletin, surat kabar, internet, hasil seminar dan sumber lainnya yang berhubungan dengan masalah yang dirumuskan. ${ }^{9}$ Teknik analisis penkajian dengan cara melakukan serangkaian kegiatan berupa pengumpulan data, pengolahan data dan menganalisis data yang diambil dari berbagai literatur yang saling berkaitan dan melengkapi sehingga dapat megambarkan tentang keterampilan kepemimpinan kepala madrasah dalam pengelolaan guru dan karyawan. ${ }^{10}$

\section{HASIL DAN PEMBAHASAN}

\section{Konsep Kepemimpinan Kepala Sekolah}

Kepemimpinan merupakan proses

9 Kartini Kartono, Pengantar Metodelogi Risetv Sosial, Bandung: Mandar Maju, 1996, hlm. 6

10 Nazir Mohammad, Metode Penelitian, Jakarta: Chalia Indonesia, 1988, hlm. 202 
mempengaruhi, memotivasi dan memperbaiki perilaku pengikut untuk bekerja dalam rangka pencapaian tujuan organisasi pendidikan di madrasah. ${ }^{11}$ Menurut Miftah Thoha kepemimpinan merupakan hubungan antara seseorang dengan orang lain untuk mempengaruhi orang lain agar bersedia bekerja bersama-sama terhadap tugas yang berkaitan dengan pencapai tujuan yang diinginkan. ${ }^{12}$

Kepala madrasah sebagai tenaga fungsional guru yang diberikan tugas tambahan untuk memimpin suatu madrasah yang menyelenggarakan proses belajar mengajar atau tempat tenjadi interaksi antara guru yang memberi pelajaran dan murid yang menerima pelajaran. ${ }^{13}$ Menurut Wahjosumidjo mengatakan kepala madrasah merupakan jabatan pemimpin yang tidak bisa diisi oleh orang-orang tanpa didasarkan atas pertimbangan-pertimbangan tertentu terhadap seseorang yang diangkat menjadi kepala madrasah. ${ }^{14}$

Berdasarkan uraian tersebut diatas, dapat disimpulkan bahwa kepemimpinan kepala madrasah merupakan kemampuan dan wewenang dalam mempengaruhi, mengarahkan, menggerakkan dan mendorong timbulnya motivasi dan semangat serta percaya diri para guru dan karyawan untuk melaksanakan tugas yang diamanahkan kepadanya demi kemajuan dan pencapaian tujuan pendidikan di madrasah.

11 Nurhasanah, Kepemimpinan Kepala Sekolah Dalam Pengembangan Lembaga Pendidikan, Jurnal At-Iltizam, Vol. 2 No.1, Juli 2017

12 Miftah Thoha, Kepemimpinan Dalam Manajemen Suatu Pendekatan, Jakarta: PT. Grafindo Persada, 1999, hlm. 89

13 Soebagyo Atmodiwiro, Manajemen Pendidikan Indonesia, Jakarta: Ardadizya Jaya, 2003, hlm. 112

14 Wahjosumidjo, Kepemimpinan Kepala Sekolah Profesional, Bandung: PT Remaja, 2001, hlm. 17
Pengelolaan madrasah harus benar-benar dipimpin oleh seseorang kepala madrasah yang memiliki keterampilan kepemimpinan, sebab keberhasilan penyelenggaraan pendidikan di madrasah sangat ditentukan oleh keterampilan kepemimpinan kepala madrasah selaku motor penggerak aktivitas program pendidikan di madrasah. Keterampilan kepemimpinan kepala madrasah sebagai seorang menejer meliputi: pertama, manusia sebagai faktor penggerak utama aktivitas madrasah, kedua money yaitu sebagai modal aktivitas, ketiga method sebagai alat untuk mengarahkan manusia dan uang menjadi efektif dalam pencapaian tujuan pendidikan di madrasah. ${ }^{15}$

Dalam kepemimpinan memiliki beberapa prinsip kepemimpinan yang harus dipahami oleh seorang kepala madrasah dalam mengelola guru dan karyawan di madrasah. Prinsip-prinsip kepemimpinan secara umum antara lain: 1) konstruktif: kepala madrasah harus memberikan dorongan dan pembinaan kepada setiap guru dan stafnya untuk mengembang kemampuannya secara optimal, 2) kreatif: kepala madrasah jangan terjebak kepada pola-pola kerja lama yang dikerjakan oleh kepala madrasah sebelumnya, 3) partisipasif: memberikan kepercayaan kepada semua pihak untuk selalu terlibat dalam setiap aktivitas madrasah, 4) kooperatif: kepala madrasah harus senantiasa bekerja sama dengan semua komponen yang terkait dalam melaksanakan setiap kegiatan, 5) delegatif: kepala madrasah berupaya memberikan kepercayaan kepada guru dan karyawan untuk melaksanakan tugas sesuai dengan kemampuan

15 Mulyasa E, Menjadi Kepala Sekolah Profesional, Bandung: PT. Remaja, 2001, hlm. 21 
dan deskripsi tugas/jabatan, 6) Integratif: untuk menghasilkan suatu sinergi yang besar, kepala madrasah harus mengintegrasikan semua kegiatan agar tujuan madrasah dapat tercapai, 7) rasional dan objektif: kepala madrasah berupaya untuk menjadi pemimpin yang bijak dalam melaksanakan tugasnya dan bertindak berdasarkan pertimbangan rasio dan objektif, bukan dengan emosional, 8) pragmatis: kepala madrasah dalam menetapkan kebijakan dan target harus berdasarkan pada kondisi dan kemampuan riil yang dimiliki oleh madrasah., 9) tidak memaksa diri untuk melakukan di luar kemapuan dan target, 10) keteladanan: kepala madrasah sebagai seorang figur yang patut memberikan keteladanan kepada seluruh staf, guru dan para siswa, dan 11) adaptable dan fleksibel: kepala madrasah harus mampu beradaptasi dan fleksibel dalam menghadapi situasi baru dan juga menciptakan kondisi kerja yang mendukung staf untuk cepat beradaptasi. 16

Kepala sekolah yang sukses sangat berpegang teguh untuk mengikuti prinsipprinsip kepemimpinan dalam mempengaruhi, membina dan menggerakkan guru dan karyawan dalam melaksanakan tugas yang diamanahkan kepadanya. Prinsip-prinsip kepemimpinan tersebut dapat dipraktekkan oleh kepala madrasah sesuai dengan situasi dan kondisi madrasah yang ia pimpin. Kemudian prinsip-prinsi tersebu menjadi landasan moral bagi seorang pemimpin dalam mengelola dan mempengaruhi guru dan karyawan di madrasah.

Kalau dilihat dari sudut pandang fungsinya, kepala madrasah berfungsi

\footnotetext{
16 Wahjosumidjo, Kepemimpinan Kepala Sekolah hlm 24
}

sebagai perumus tujuan kerja dan penentu kebijakan madrasah, pengatur tata kerja madrasah, seperti pengaturan pembagian tugas guru dan karyawan, serta penyeleggaraan kegiatan program madrasah, dan melakukan supervisi terhadap tugas yang dilaksanakan guru dan karyawan, seperti mengatur dan membimbing tugas guru dan karyawan serta mengevaluasi terhadap pelaksanaan kegiatan, dan meningkatkan kemampuan pelaksana tugas guru dan karyawan. ${ }^{17}$

Kemudian, kepala madrasah tidak cukup menguasai teori-teori kepemimpinan semata, akan tetapi hal yang sangat penting bagaimana keterampilan mengimplementasikan teori-teori secara nyata. ${ }^{18}$ Kepala madrasah seharusnya dapat berperan sebagai, pertama sebagai educator (pendidik), yaitu berusaha menanamkan akhlak yang baik kepada guru dan karyawan, kedua sebagai manager (pengelola), yaitu merencanakan, mengorganisasikan, memimpin dan mengendalikan guru dan karyawan agar dapat melaksanakan tugas dengan baik, ketiga sebagai administrator, yaitu penanggung jawab terhadap kelancaran pelaksanaan administrasi guru dan karyawan, keempat sebagai supervisor, yaitu meneliti, mencari, dan menentukan syarat-syarat mana saja yang diperlukan oleh lembaga, kelima sebagai leader (pemimpin), yaitu memberikan petunjuk, dan pengawasan serta memenuhi kebutuhan guru dan karyawan, berkomunikasi dua arah dan mendelegasikan tugas, keenam sebagai inovator, yaitu mencari, menemukan

17 Daryanto, Administrasi Pendidikan, Jakarta: Reneka Cipta, 2001, hlm. 81

18 Dedi Lazwardi, Peran Kepala Sekolah Dalam Meningkatkan Profesionalisme Guru, Universitas Nahdlatul Ulama Lampung, 804-1366-1. pdf, hlm. 148 
dan melaksanakan berbagai pembaruan dan tujuh sebagai motivator, yaitu memiliki strategi yang tepat untuk memberikan motivasi kepada guru dan karyawan dalam bidang tugas dan fungsinya. ${ }^{19}$

\section{Kerangka Konsepsional Keterampilan Kepemimpinan Kepala Madrasah Dalam Pengelolaan Guru dan Karyawan}

Beranjak dari konsep kepemimpinan kepala madrasah dalam pengelolaan guru dan karyawan, maka kerangka konsepsional dapat didesain, meliputi: keterampilan mengorganisir, dan mengarahkan guru, dan karyawan, keterampilan memupuk kepercayaan diri kepada guru dan karyawan, keterampilan membangun kerja sama dalam pengembangan profesi guru dan karyawan, keterampilan membangun team work yang kompak dan kokoh serta keterampilan mendorong partisipasi guru, dan karyawan dalam pencapaian tujuan madrasah.

Skema desain keterampilan kepemimpinan kepala sekolah dalam mengelola guru dan karyawan adalah sebagai berikut:

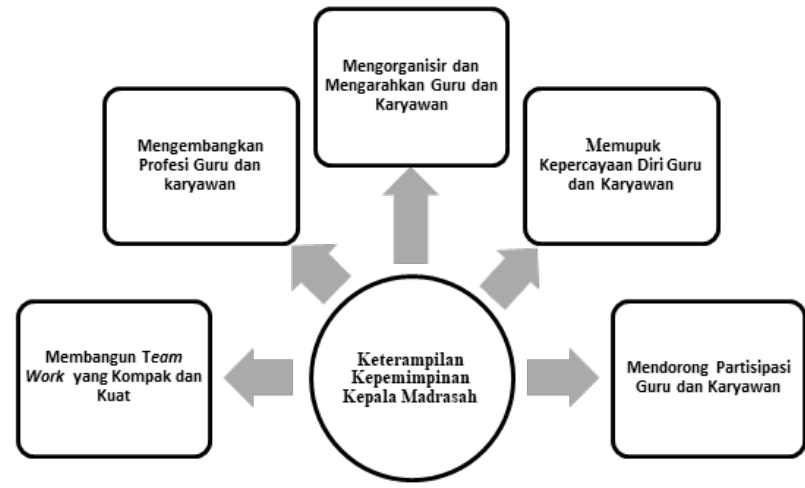

Gambar: Desain Keterampilan Kepemimpinan Kepala Madrasah

Kelima indikator keterampilan

19 E. Mulyasa, Menjadi Kepala Sekolah Profesional, Bandung: Remaja Rosda Karya, 2004, hlm. 98 kepemimpinan kepala madrasah saling menguat satu sama lain dalam mengelola guru dan karyawan dalam upaya peningkatan kinerja di madrasah.

\section{Keterampilan Kepemimpinan Kepala}

Madrasah dalam Pengelolaan guru dan karyawan

Kepala sekolah sebagai pengelola guru dan karyawan sangat dituntut memiliki keterampilan kepemimpinan dalam hal mengorganisir dan mengarahkan dan keryawan, memupuk kepercayaan diri guru, dan karyawan, mengembangkan profesi guru, dan karyawan, membangun team work yang kompak dan kokoh serta mendorong partisipasi guru, dan karyawan dalam pencapaian tujuan madrasah. Keterampilan-keterampilan kepemimpinan tersebut dapat dijadikan sebagai kunci dalam meraih kesuksesan kepemimpinan kepala madrasah dalam mengelola guru dan karyawan di madarasah.

1. Keterampilan mengorganisir dan mengarahkan guru, dan keryawan

Kepala madrasah yang profesional senantiasa memiliki keterampilan mengorganisir dan mengarahkan guru dan karyawan pada saat mareka menjalankan kegiatan program pendidikan di madrasah. Mengorganisir guru dan karyawan dapat dilakukan dengan cara memberikan pandangan-pandangan supaya mareka paham dan mengerti terhadap tugas yang akan mareka lakukan. Karena kalau guru dan karyawan sudah paham dan mengerti terhadap tugas apa yang harus mareka lakukan, maka dengan mudah mareka menyelesaikan tugas apa yang menjadi 
tanggung jawabnya. ${ }^{20}$

Kepala madrasah dalam memberikan pengarahan kepada guru dan karyawan harus bersifat konstruktif supaya mareka dapat mengembangkan kemampuan pribadi secara optimal. ${ }^{21}$ Untuk itu kepala madrasah berkewajiban memberikan pengarahan kepada guru dan karyawan supaya mareka terpanggil jiwa dan raga untuk bekerja dengan sungguh-sungguh, disiplin dan amanah sesuai menurut kepercayaan yang diberikan kepadanya.

Keterampilan mengorganisir dan memberikan pengarahan kepada guru dan karyawan dapat memberi pengaruh besar terhadap hasil kerja guru dan karyawan. "Keterampilan mengorganisir sumber daya manusia dapat dilakukan dengan cara memberikan pengarahan kepada guru dan karyawan sesuai menurut standar operasional prosudural (SOP) dan penerapan mekanisme perukrutan". ${ }^{22}$ Sedangkan pengarahan kepada guru dan karyawan dapat dilakukan dengan cara memberi petunjuk kepada guru dan karyawan agar mareka dapat bekerja secara efektif dan efesien untuk pencapaian tujuan pendidikan. ${ }^{23}$

\section{Keterampilan memupuk kepercayaan diri guru dan karyawan}

Kepala madrasah sebagai pigur

20 Sugeng Sejati, Urgensi MSDM Sebagai Nilai Strategis dalam Mencapai Target Perusahaan, Jurnal Baabu Al-ilmi, Volume 5, Nomor 1, April 2020, hlm. 24

21 Wahjosumidjo, Kepemimpinan Kepala Sekolah ........... hlm 24

22 Sugeng Sejati, Urgensi MSDM Sebagai Nilai Strategis ., hlm. 26

23 Sugeng Sejati, Urgensi MSDM Sebagai Nilai Strategis hlm. 27 keteladan bagi semua aparatur madrasah, termasuk di dalamnya guru dan karyawan, maka diharapkan kepada kepala madrasah harus memiliki keterampilan dalam membangun dan memupuk kepercayaan diri guru dan karyawan supaya mareka dapat bekerja sesuai yang diamanahkan kepadanya. Penanaman nilai kepercayaan diri guru dan karyawan bukan hanya dari aspek keberanian semata, melainkan yang sangat penting adalah memupuk kepercayaan diri terhadap penerapan disiplin dan bertanggung jawab terhadap tugasnya.

Efektifitas kepemimpinan kepala madrasah terlihat apa bila mampu memupuk kepercayaan diri guru sebagai pengajar dan pendidik serta karyawan sebagai pelaksana teknis dalam bidang administrasi madrasah untuk menunjang kelancaran program pendidikan dan kemajuan madrasah. ${ }^{24}$ Kepala madrasah sebagai penganyom guru dan karyawan tidak boleh lelah dan letih untuk membangun kepercayaan diri guru dan karyawan dalam bekerja dan berinteraksi dengan rekan kerja dan atasannya.

Kepala marasah yang memiliki keterampilan memupuh kepercayaan diri guru dan karyawan sangatlah urgen dimiliki oleh seorang kepala madarah supaya guru dan karyawan merasa percaya diri terhadap pekerjaan yang mareka lakukan. Kepala madrasah berkewajiban secara terus menerus melakukan pembinaan kepada guru dan karyawan supaya mareka terpelihara sikap

24 Mukhtar, Strategi Kepala Sekolah Dalam Meningkatkan Kinerja Guru pada SMP Negeri Di Kecamatan Masjid Raya Kabupaten Aceh Besar, Jurnal Magister Administrasi Pendidikan Universitas Syiah Kuala, ISSN 2302-0180, Volume 3, No. 3, Agustus 2015, hlm. 107 
percaya diri dalam bekerja dan menhadapi tantangan terhadap pekerjaan yang diamanahkan kepadanya. ${ }^{25}$

\section{Keterampilan mengembangkan profesi} guru dan karyawan

Kepala madrasah sebagai manager (pengelola) memiliki kewajiban mengembangkan profesi guru dan karyawan dalam bekerja agar mareka dapat meningkatkan kemampuan diri dari aspek keilmuannya maupun dari aspek keterampilan yang dapat meningkatkan kinerja dan karirnya. Kepala madrasah dalam pengembangan profesi guru dan karyawan tidak boleh bersikap pilih kasih terhadap guru dan karyawan, akan tetapi memberikan kesempatan yang sama kepada semua personil di bawah kepemimpinannya. Sebab semakin banyak kesempatan pengembangan profesinya, maka semakin profesional guru dan karyawan dalam melaksanakan tugasnya.

Dalam hal pengembangan profesi guru, kepala madrasah dapat mengarahkan guru untuk mengikuti program kegiatan yang diselenggarakan oleh Forum Musyawarah Guru Mata Pelajaran (MGMP), Kelompok Kerja Guru (KKG) dan berbagai pelatihan lainnya yang diselenggaran pihak jajaran dinas pendidikan dan kementerian Agama. ${ }^{26}$ Melalui program dan kegiatan pengembagan profesi guru, kepala madrasah dapat mengarahkan dan menginstruksikan guru untuk dapat bekerja sesuai dengan ilmu yang didapat dalam kegiatan MGMP dan KKG

25 Efi Brata Madya, Pentingnya Pembinaan Sumber Daya Manusia .........., hlm. 10

26 Mukhtar, Strategi Kepala Sekolah Dalam Meningkatkan Kinerja Guru...........hlm. 103 tersebut.

Kemudian kepala madrasah dalam pengembangan profesi karyawan dapat mengadakan berbagai pelatihan berupa workshop dan training serta webinar untuk menambah keilmuan dan mengubah perilaku karyawan dalam bekerja. Pengembangan profesi karyawan dilakukan secara terus menerus dalam rangka peningkatan keahlian (skill) dan kemampuan (abilities) untuk dapat mengerjakan tugas dengan baik hari ini dan masa yang akan datang. ${ }^{27}$

\section{Keterampilan membangun team work} yang kompak dan kokoh

Keterampilan membangun team work bagi seorang kepala madrasah merupakan proses mengintegrasikan dua kepentingan antara kepentingan Imadrasah dengan kepentingan guru dannkaryawan. "Mengintegrasikan dua kepentingan antara madrasah dengan guru dan karyawan untuk mewujudkan kesesuaian supaya tercipta kerja sama yang serasi dan saling menguntungkan. Pengintegrasian adalah hal yang penting dan sulit dibangun tanpa kesadaran dalam membentuk team work yang dapat mempersatukan dua aspirasi atau kepentingan yang bertolak belakang antara guru dan karyawan dengan lembaga pendidikan. ${ }^{28}$

Kepala madrasah sebagai pemimpin sangat komit dan konsisten membangun team work yang kompak dan kokoh dalam

27 Suparwi, Urgensi Pengelolaan Sumber Daya Manusia Dalam Bisnis Di Era Kontemporer, Jurnal Penelitian, Vol. 12, No. 1, Februari 2018

28 Efi Brata Madya, Pentingnya Pembinaan Sumber Daya Manusia Dalam Organisasi Dakwah, Jurnal Al-Idarah, Volume 5, Nomor 6, 2018, hlm. 9 
mengemban madrasah sebagai satuan pendidikan. Kepala madrasah dapat menjaga kondisi madrasah supaya tetap nyaman dan aman sepanjang masa. "Kepala madrasah sebagai menejer sangat dituntut mengembangkan hubungan kerja sama yang baik antara kepala madrasah, guru dan masyarakat guna mewujudkan yang efektif dan efisien dalam bekerja. Kemudian kepala madrasah harus mampu memupuk dan menjalain hubungan kerja sama yang baik dengan warga madrasah maupun dengan masyarakat yang ada di lingkungan madrasah". ${ }^{29}$

Membangun team work yang kompak dan kokoh perlu dijaga ketat oleh kepala madrasah. Karena kalau rusak team work di madrasah akan menggoroti kepemimpinan kepala madrasah sepanjang masa kepemimpinannya. Oleh karena itu kepala madrasah ada perhatiann lebih untuk menjaga motto maju bersama dan bersama kita bisa. Motto ini harus dijadikan sebagai prinsip moral untuk menjaga kelanggengan team work yang kompak dan kokoh dalam kepemimpinannya.

\section{Keterampilan mendorong partisipasi guru dan karyawan dalam pencapaian tujuan madrasah}

Guru dan karyawan tidak boleh sunyi dari berbagai macam motivasi diberikan oleh kepala madrasah agar mareka tetap selalu berpartisipasi dalam pencapaian tujuan program pendidikan di madrasah. Kepala madrasah selaku pemimpin sekaligus

29 Mukhtar, Strategi Kepala Sekolah Dalam Meningkatkan Kinerja Guru..... hlm. 104 sebagai manajer harus menagtur dan memberi perintah kepada guru dan karyawan untuk berperan aktif untuk melaksanakan berbagai program dan kegiatan madrasah serta sekaligus mengayomi mareka dalam menyelesaikan masalah-masalah yang sedang mareka hadapi. ${ }^{30}$

Kepala madrasah sangat diperlukan memberikan kompensasi dan proteksi terhadap guru dan karyawan agar mareka termotivasi untuk melakukan yang terbaik. Kompensasi adalah imbalan atas kontribusi kerja guru dan karyawan secara teratur dari madrasah. Kompensasi yang tepat sangat penting dan disesuaikan dengan guru, karyawan dan madrasah. Kompensasi yang tidak sesuai dengan kondisi yang ada dapat menyebabkan masalah ketenaga kerjaan dikemudian hari yang menyebabkan kerugian bagi madrasah. ${ }^{31}$

Kepala madrasah sangat urgen memiliki keterampilan dalam mendorong partisipasi guru dan karyawan untuk bekerja dengan gigih, disiplin dan tanggung jawab terhadap tugas yang diamanahkan kepadanya. Karena semakin cerdas dan terampil kepala madrasah mendorong partisipasi guru dan karyawan, maka semakin aktif dan kreatif guru dan karyawan bekerja untuk meningkatkan kinerjanya.

\section{KESIMPULAN}

Berdasarkan hasil pembahasan dapat disimpulkan bahwa kepala madarasah yang

30 Dedi Lazwardi, Peran Kepala Sekolah Dalam Meningkatkan ..........hlm. 144

31 Efi Brata Madya, Pentingnya Pembinaan Sumber Daya Manusia .........., hlm. 9 
sukses dalam kepemimpinannya apa bila ia memiliki keterampilan mengorganisir dan menggerakkan guru, dan keryawan, memiliki keterampilan memupuk kepercayaan diri guru, dan karyawan, memiliki keterampilan mengembangkan profesi guru, dan karyawan, memiliki keterampilan membangun team work yang kompak dan kokoh, dan memiliki keterampilan mendorong partisipasi guru, dan karyawan dalam pencapaian tujuan pendidikan di madrasah.

\section{DAFTAR PUSTAKA}

Ahmad Mujaddid, dkk, Pengembangan Sumber Daya Manusia Dalam Pendidikan, Junal Project Pengembangan SDM Dalam Pendidikan, Universitas Islam Negeri Alauddin, Januari 2019 Abudin Nata, Perspektif Islam Tentang Strategi Pembelajaran, Jakarta: Kencana, 2009

Daryanto, Administrasi Pendidikan, Jakarta: Reneka Cipta, 2001

Dedi Lazwardi, Peran Kepala Sekolah Dalam Meningkatkan Profesionalisme Guru, Universitas Nahdlatul Ulama Lampung, 804-1366-1

Efi Brata Madya, Pentingnya Pembinaan Sumber Daya Manusia Dalam Organisasi Dakwah, Jurnal Al-Idarah, Volume 5, Nomor 6, 2018

Kartini Kartono, Pengantar Metodelogi Risetv Sosial, Bandung: Mandar Maju, 1996 Kasidah, dkk, Kepemimpinan Kepala sekolah dalam Meningkatkan Kinerja Guru Pada sekolah Dasar Luar Biasa, Jurnal Magister Administrasi Pendidikan Pascasarjana Universitas Syiah Kuala, Volume 5, No. 2, Mei
2017

Peraturan Pemerintah, Nomor: 28 Tahun 1990, Tentang Pendidikan Dasar, tanggal 10 Juli 1990

Peraturan Menteri Pendidikan Nasional, Nomor 13 Tahun 2007, Tentang Standar Kepala Sekolah/Madrasah

Peraturan Menteri Pendidikan Nasional, Nomor 6 Tahun 2018, Tentang Penugasan Guru Sebagai Kepala Sekolah

Usman, H, Manajemen Teori, Praktik, dan Riset Pendidikan, Jakarta: Bumi Aksara, 2009

Miftah Thoha, Kepemimpinan Dalam Manajemen Suatu Pendekatan, Jakarta: PT. Grafindo Persada, 1999

Mulyasa E, Menjadi Kepala Sekolah Profesional, Bandung: PT. Remaja, 2001

Mulyasa E, Menjadi Kepala Sekolah Profesional, Bandung: Remaja Rosda Karya, 2004

Mukhtar, Strategi Kepala Sekolah Dalam Meningkatkan Kinerja Guru pada SMP Negeri Di Kecamatan Masjid Raya Kabupaten Aceh Besar, Jurnal Magister Administrasi Pendidikan Universitas Syiah Kuala, ISSN 23020180, Volume 3, No. 3, Agustus 2015

Nazir Mohammad, Metode Penelitian, Jakarta: Chalia Indonesia, 1988

Nurhasanah, Kepemimpinan Kepala Sekolah Dalam Pengembangan Lembaga Pendidikan, Jurnal At-Iltizam, Vol. 2 No.1, Juli 2017

Soebagyo Atmodiwiro, Manajemen Pendidikan Indonesia, Jakarta: Ardadizya Jaya, 2003

Sugeng Sejati, Urgensi MSDM Sebagai Nilai 
Strategis dalam Mencapai Target Stephen R. Covey, Kepemimpinan Berprinsip, Perusahaan, Jurnal Baabu Al-ilmi, Jakarta: Bina Pura Aksara, 1977

Volume 5, Nomor 1, April 2020

Syafrida, Kepemimpinan Kepala Sekolah,

Suparwi, Urgensi Pengelolaan Sumber Daya Jurnal Manajer Pendidikan, Volume Manusia Dalam Bisnis Di Era 9, Nomor, November 2015

Kontemporer, Jurnal Penelitian, Vol. Wahjosumidjo, Kepemimpinan Kepala Sekolah 12, No. 1, Februari 2018

Profesional, Bandung: PT Remaja, 2001 